\title{
N-Substituted amino acids as multifunctional additives used in cooling water. I. N-Hydroxymethyl amino acids
}

\author{
J. Telegdi ${ }^{1,2}$ and J. Beczner ${ }^{3}$ \\ ${ }^{1}$ Department of Interfaces and Surface Modification, Institute of Materials \\ and Environmental Chemistry, Research Centre for Natural Sciences, \\ Hungarian Academy of Sciences, Magyar tudósok körútja 2, 1117 Budapest, Hungary \\ *E-mail: telegdi@chemres.hu \\ ${ }^{2}$ Óbuda University, Faculty of Light Industry and Environmental Engineering, \\ Doberdó u. 6., 1034 Budapest, Hungary \\ ${ }^{3}$ Central Environmental and Food Science Research Institute, Herman Ottó út 15., \\ 1022 Budapest, Hungary
}

\begin{abstract}
The aim of our research was to synthesize and apply chemicals that can control both the electrochemical and microbiological corrosion. In order to achieve this result Nhydroxymethylated amino acids were synthesized and used as corrosion inhibitors and as biocides. With weight loss tests and linear polarisation experiments were proven their efficiency as corrosion inhibitors. The biocide activity was measured in microbiological experiments. It was important to learn whether these molecules can control the growth both of the planktonic as well as of the biofilm-embedded microbes, too. With different calculations correlation was found between the molecular structure and their efficiency.
\end{abstract}

Key words: Corrosion, microbiologically influenced corrosion, inhibition, biocide, $N$ hydroxymethyl amino acid.

Received: May 15, 2014.

doi: $\underline{10.17675 / 2305-6894-2014-3-3-167-176}$

\section{Introduction}

Waters used in different industrial cooling systems contain not only ions, organic-inorganic molecules but several microorganisms, too. Some of them are responsible for the microbiologically influenced corrosion (MIC). In this case the presence of microbes and their metabolites increase the rate of the corrosive deterioration [1-9]. From the point of view of MIC the most aggressive microorganisms are the sulphate reducer bacteria (SRB). The anaerobic SRBs produce sulphide from sulphate ions and they form with the iron ions insoluble iron sulphide. Due to this mechanism the corrosion rate increases significantly.

In order to reduce the influence of the aggressive chemicals and the microbes additives are dissolved in the cooling water. There are a wide range of the corrosion inhibitors. Under neutral conditions phosphonic acids are the most effective anticorrosive additives [10-19]. But it is important to handle the problem of the scaling as well as of the microbial deterioration. The scale formation is generally reduced by addition of different 
polymers $[20,21]$. The cooling water additives contain other chemicals that can control the activity of the corrosion relevant microorganisms. The biocides can kill the microorganisms; the biostatic materials can only keep the cell number at constant level. The other problem is that in order to control the rate of MIC we have to reduce not only the number of the planktonic bacteria but also of those which are embedded into a biofilm. The biofilm forms on all solid surfaces when microbes are present and to handle these microorganisms needs much higher biocide concentration then to decrease the number of the planktonic cells.

In the water handling chemicals of different types are parallel used; one of them controls the chemical and electrochemical corrosion, the other one reduces the scale formation [20,21], and the third one decreases the activity of microbes [22-26]. In all cases it is necessary to harmonize the application of all chemicals used at the same time in order to avoid the incompatibility. But generally three different chemicals are used.

The aim of our work was to use molecules which are able not only to decrease the chemical/electrochemical corrosion rate, but, at the same time, to control the microbial growth, microbial activity. This goal was achieved by special, N-substituted amino acids. The basic molecules are natural compounds and after the decomposition of the substituted amino acids, environmentally benign molecules are formed that do not spoil the nature.

\section{Experimental}

The N-hydroxymethylated amino acids were synthesized at our institute via reaction of alkaline solution of amino acids with formaldehyde [27, 28]. The substituted molecules were: N-hydroxymethyl glycine/phenylalanine/serine/glutamic acid, they were characterized and used as received.

The corrosion rates were determined by weight loss test (WLT) as well as by linear polarization technique. The efficiency $(\eta, \%)$ was calculated according to the equation (1):

$$
\eta=\frac{m_{0}-m_{i}}{m_{0}} \times 100[\%]
$$

where $m_{0}$ represents the weight of the coupon before the experiment, $m_{i}$ is the weight of the coupon after the experiment when the rust is already removed.

The solutions used in WLT were either model solution $\left(\left[0.47 \mathrm{~g} \mathrm{CaSO}_{2} \times 2 \mathrm{H}_{2} \mathrm{O}+\right.\right.$ $\left.0.23 \mathrm{~g} \mathrm{MgSO}_{4} \times \mathrm{H}_{2} \mathrm{O}+0.11 \mathrm{~g} \mathrm{NaHCO}_{3}+0.13 \mathrm{~g} \mathrm{CaCl}_{2} \times \mathrm{H}_{2} \mathrm{O}\right] / 1 \mathrm{~L}$ distilled water, $\mathrm{pH}=7$ ) or cooling water. The inhibitor/biocide concentration is shown in all cases.

The linear polarisation experiments were performed in cooling water.

In our experiments either Desulfovibrio desulfuricans isolated microorganisms (ATCC 7757; culture media: ATCC 1249; general cell number: $10^{6}$ cell $/ \mathrm{cm}^{3}$ )) or the mixed culture of cooling water were applied. For cell number calculation microbiological methods were used. 


\section{Results and Discussion}

\section{Corrosion inhibition results got by WLT}

Table 1. Anticorrosion efficacy measured in the presence of N-hydroxmethyl (NHM) amino acids; the red-colour characters represent the differences in the molecules.

\begin{tabular}{lcc}
\hline NHM amino acid & $\boldsymbol{\eta}$ [\%] (50 ppm) & $\boldsymbol{\eta}$ [\%] (500 ppm) \\
\hline HO- $\mathbf{C H}_{2}-\mathrm{NH}-\mathrm{CH}_{2}-\mathrm{COOH}$ & 51.1 & 88.2 \\
$\mathbf{H O}-\mathrm{CH}_{2}-\mathrm{NH}-\mathrm{CH}\left(\mathrm{CH}_{2} \mathrm{C}_{6} \mathrm{H}_{5}\right)-\mathrm{COOH}$ & 27.3 & 73.1 \\
$\mathbf{H O}-\mathrm{CH}_{2}-\mathrm{NH}-\mathrm{CH}\left(\mathrm{CH}_{2}-\mathrm{OH}\right)-\mathrm{COOH}$ & 47.1 & 80.9 \\
$\mathbf{H O}-\mathrm{CH}_{2}-\mathrm{NH}-\mathrm{CH}\left(\mathrm{CH}_{2}-\mathrm{CH}_{2} \mathbf{C O O H}\right)-\mathrm{COOH}$ & 35.7 & 68.3 \\
\hline
\end{tabular}

The most important information got by these experiments is that the chemicals we want to use for the MIC control do not cause corrosion, on the other hand, they have a medium efficacy at low concentration; but at the much higher concentration - which generally are used in biocide experiments - they turned to be effective corrosion inhibitors.

\section{Effect of the NHM amino acids on the corrosion relevant microorganisms}

In order to know which types of chemicals can affect the multiplication and adhesion of microorganisms we had to learn more about these processes. Chemicals used against the corrosion relevant microbes can interact either with the cell membrane or with the cytoplasm and the consequence could be the inhibition of the growth, the end of the integrity of the cell wall, the leakage of the membrane and plasmolysis.

By these NHM amino acids we wanted to decrease not only the growth of the microorganisms but inhibit their adhesion to solid surfaces. If we would like to diminish the corrosive effect of microbes the first step should be the inhibition of the adhesion as in this case the formation of the biofilm is blocked. These two activities were characterized by linear polarization measurements and microbiological methods.

\section{Influence of the Desulfovibrio desulfuricans on the mild steel corrosion}

The Figure 1 demonstrates the corrosive activity of the microorganisms and the influence of the biocide (in this case the NHM phenylalanine) on the corrosion rate measured in the presence of microbes and the microbe plus chemical via linear polarisation experiments. 


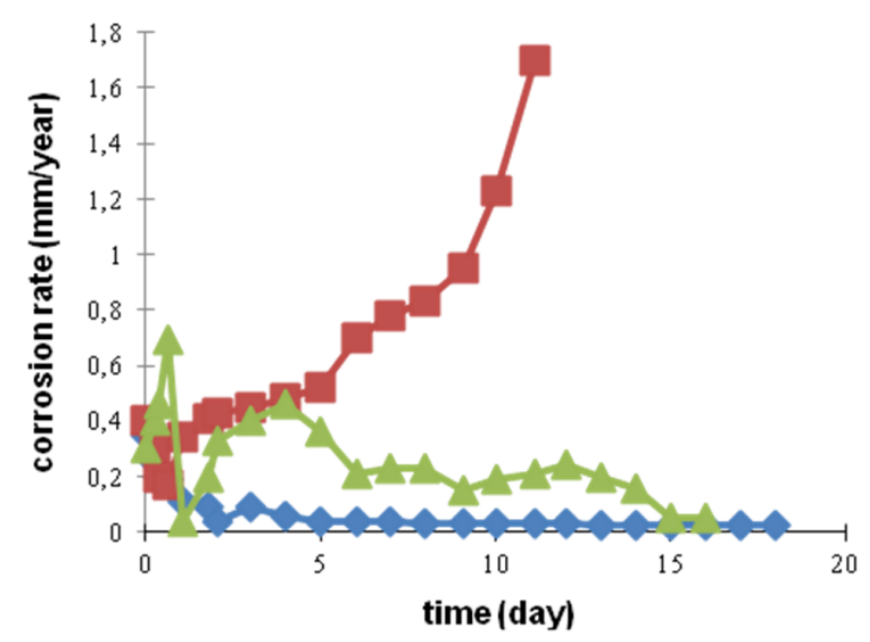

Figure 1. Mild steel electrodes in three different media: the effect of the broth $(\diamond \diamond \diamond)$, Desulfovibrio desulfuricans in the broth (घ口v), the NHM phenylalanine and the Desulfovibrio desulfuricans dissolved in the broth $(\Delta \Delta \Delta)$.

The surfaces of the electrodes are shown in the Figure 2.

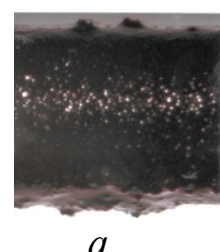

$a$

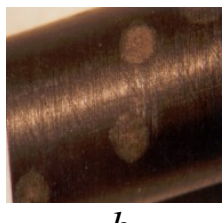

$b$

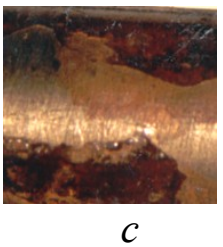

Figure 2. Electrode surfaces after immersion in the broth (ATCC 1249) inoculated with Desulfovibrio desulfuricans for 21 days; $a$ : thick blackish biofilm on the electrode; $b$ : the electrode after the removal of the blackish biofilm; $c$ : the surface of the electrode in the presence of Desulfovibrio desulfuricans and parallel with the NHM phenylalanine.

The electrochemical experimental results on the corrosion rates prove that the microorganisms increase the corrosion of the mild steel and the NHM phenylalanine (like the other NHM amino acids) decreases the corrosion i.e. the metal dissolution as well as the biofilm formation. It is interesting to observe on Figure 2 the starting places of the cell adhesion. On the photo " $a$ " not only the undesired slimy deposition is noticeable but the unevenness of the layer. When we removed this biofilm (Fig. 2b), on those places where the biolayers were thicker, the round-shaped form of the first settlements (where the biofilm formation started) is clearly visible. The Figure $2 c$ proves the effectiveness of the additive used against the cell attachment, film formation and microbial growth as the metal surface is visible and only on few places started the biofilm deposition.

In the microbiological experiments the number of the planktonic cells and of those which were embedded into the biofilm were counted. The results are summarized in Tables 2 and 3. 
Table 2. Influence of the NHM amino acids on the growth of Desulfovibrio desulfuricans cell in planktonic form and embedded in biofilms; biocide concentration: $500 \mathrm{ppm}$.

\begin{tabular}{|c|c|c|c|c|c|}
\hline NHM amino acids & $\begin{array}{c}\text { Planktonic } \\
\text { cells } \\
{\left[\mathrm{cell} / \mathrm{cm}^{3}\right]}\end{array}$ & $\begin{array}{c}\text { Planktonic } \\
\text { cells } \\
{\left[\text { cell } / \mathrm{cm}^{3}\right]}\end{array}$ & $\begin{array}{l}\text { Cells in } \\
\text { biofilm } \\
{\left[\text { cell } / \mathrm{cm}^{3}\right]}\end{array}$ & $\begin{array}{l}\text { Cells in } \\
\text { biofilm } \\
{\left[\text { cell } / \mathbf{c m}^{3}\right]}\end{array}$ & $\begin{array}{l}\text { Cells in } \\
\text { biofilm } \\
{\left[\text { cell } / \mathbf{c m}^{3}\right]}\end{array}$ \\
\hline & after 2 days & after 7 days & after 2 weeks & after 7 days & after 2 weeks \\
\hline None & $3.4 \times 10^{7}$ & $5.0 \times 10^{6}$ & $7.3 \times 10^{4}$ & $4.6 \times 10^{5}$ & $4.3 \times 10^{4}$ \\
\hline NHM glycine & $<10$ & $<10$ & $2.4 \times 10^{4}$ & $1.0 \times 10^{4}$ & $5.1 \times 10^{4}$ \\
\hline NHM phenylalanine & $<10$ & $1.8 \times 10$ & $<10$ & $1.1 \times 10^{2}$ & $2.4 \times 10^{2}$ \\
\hline NHM serine & $<10$ & $<10$ & $<10$ & $<10$ & $4.7 \times 10^{1}$ \\
\hline NHM glutamic acid & $<10$ & $1.5 \times 10$ & $1.4 \times 10$ & $2.2 \times 10$ & $3.1 \times 10^{1}$ \\
\hline
\end{tabular}

Table 3. Influence of the NHM amino acids on the growth of mixed population of cooling water in planktonic form and embedded in biofilms; biocide concentration: 500ppm.

\begin{tabular}{|c|c|c|c|c|c|}
\hline NHM amino acids & $\begin{array}{c}\text { Planktonic } \\
\text { cells } \\
{\left[\mathrm{cell} / \mathrm{cm}^{3}\right]}\end{array}$ & $\begin{array}{c}\text { Planktonic } \\
\text { cells } \\
{\left[\mathrm{cell} / \mathrm{cm}^{3}\right]}\end{array}$ & $\begin{array}{l}\text { Cells in } \\
\text { biofilm } \\
{\left[\text { cell } / \mathrm{cm}^{3}\right]}\end{array}$ & $\begin{array}{l}\text { Cells in } \\
\text { biofilm } \\
{\left[\text { cell } / \mathrm{cm}^{3}\right]}\end{array}$ & $\begin{array}{l}\text { Cells in } \\
\text { biofilm } \\
{\left[\text { cell } / \mathbf{c m}^{3}\right]}\end{array}$ \\
\hline & after 2 days & after 7 days & after 2 days & after 7 days & after 2 weeks \\
\hline None & $5.3 \times 10^{6}$ & $2.7 \times 10^{6}$ & $3.4 \times 10^{6}$ & $2.4 \times 10^{6}$ & $9.2 \times 10^{5}$ \\
\hline NHM glycine & $<10$ & $<10$ & $1.9 \times 10^{2}$ & $<10$ & $1.1 \times 10$ \\
\hline NHM phenylalanine & $<10$ & $4.4 \times 10$ & $<10$ & $1.7 \times 10$ & $9.3 \times 10^{4}$ \\
\hline NHM serine & $<10$ & $<10$ & $<10$ & $<10$ & $5.9 \times 10$ \\
\hline NHM glutamic acid & $<10$ & $2.3 \times 10$ & $1.7 \times 10$ & $8.7 \times 10$ & $9.7 \times 10$ \\
\hline
\end{tabular}

The amino acids differed in the side chain. The glycine has a hydrogen atom in the $\alpha$ position, the phenylalanine a phenylmethyl group $\left(-\mathrm{CH}_{2} \mathrm{C}_{6} \mathrm{H}_{6}\right.$, very hydrophobic), the side group of the serine $\left(-\mathrm{CH}_{2}-\mathrm{OH}\right)$ and the glutamic acid $\left(\mathrm{HOOC}-\mathrm{CH}_{2} \mathrm{CH}_{2}-\right)$ are hydrophilic (Figure 3). In these experiments NHM amino acids either with hydrophobic or with hydrophilic side chain can efficiently control a microbial growth both in the planktonic state and in the biofilms. After two weeks, the efficiency decreased only in the presence of the NHM phenylalanine in the case of the mixed population of cooling water but not at the anaerobic Desulfovibrio desulfuricans. In any other cases the number of the microorganisms was $10^{4}$ times less than that of the control. It shows that the hydrophilic side chains - either $\mathrm{OH}$ or $\mathrm{COOH}$ - show beneficial effect on the growth of the corrosion relevant microorganisms. 

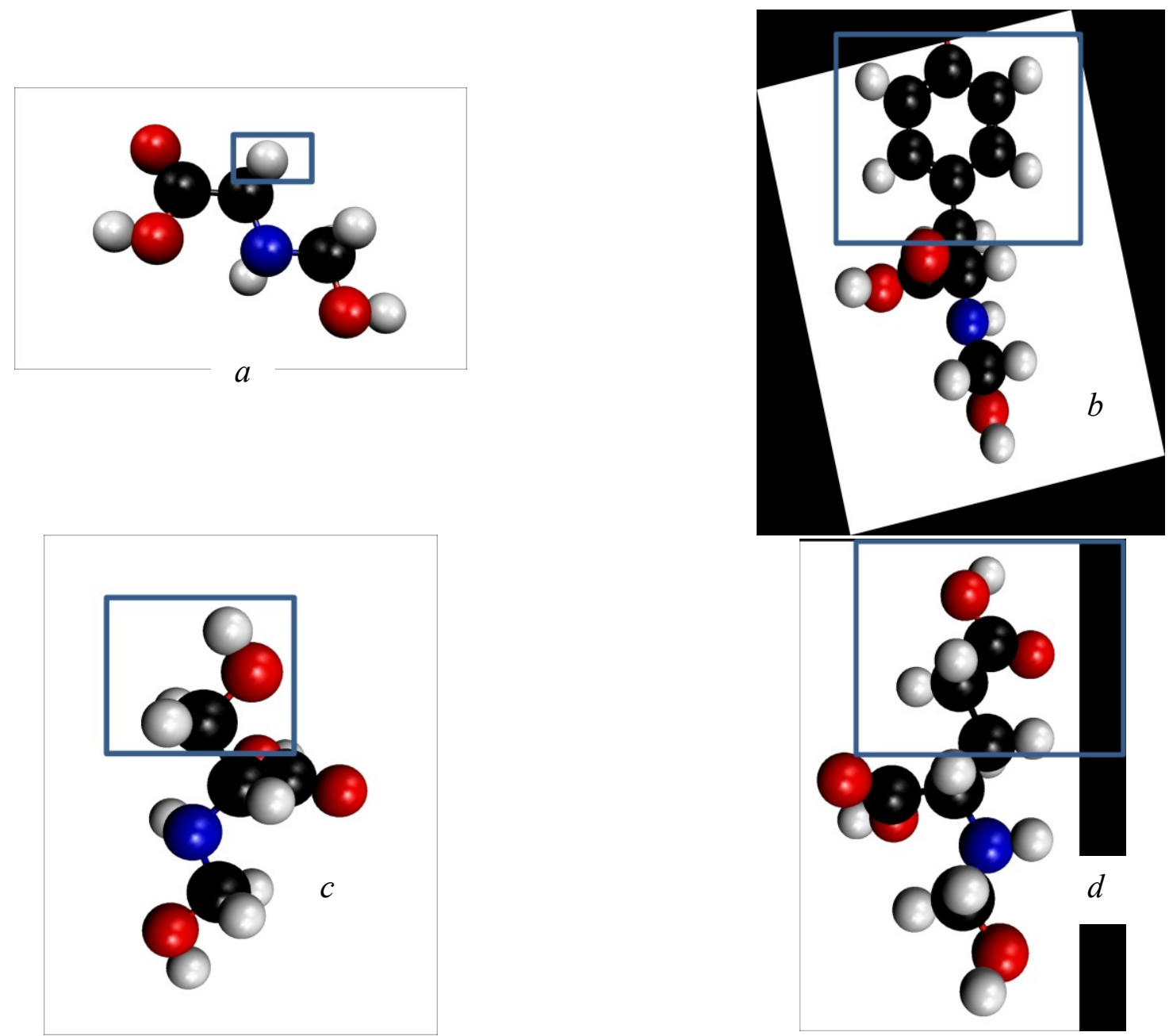

Figure 3. Differences in the side chain of the NHM amino acid; $a$ : NHM glycine (H); $b$ : NHM phenylalanine $\left(\mathrm{HC}_{2} \mathrm{C}_{6} \mathrm{H}_{5}\right) ; c$ : NHM serine $\left(\mathrm{CH}_{2} \mathrm{OH}\right) ; d$ : NHM glutamic acid $\left(\mathrm{CH}_{2} \mathrm{COOH}\right)$.

Table 4 allows us the comparison of the anticorrosion efficiency and the inhibition of microorganisms (i.e. the inhibition of the microbiologically influenced corrosion), in both cases of the pure culture and the mixed population of cooling water.

These results prove that especially the serine and glutamic acid derivatives can control both the electrochemical corrosion as well as the microbiologically influenced corrosion. It is also important that they effectively inhibit the growth of both the planktonic population and of those microbes embedded in biofilm. This is very important because the penetration into the matrix of the biofilm is not easy; generally it needs much higher biocide concentration. The main organic components of the biofilm are the so-called exopolymeric substances which consist of exopolysaccharides as basic materials and of proteins, nucleic acids etc. The effectiveness of the NHM serine and NHM glutamic acid can be explain with the compatibility of the hydrophilic EPS with the ionic $(\mathrm{COOH})$ and polarisable $(\mathrm{OH})$ groups. This allows an easy penetration of substituted amino acids into the biofilm and an interaction with the cell wall, cell membrane. The crossing the cell wall of these molecules results in their decomposition within the cell and the freely formed formaldehyde interact 
with free amino groups, destroy the cell wall and can cause the coagulation of the plasma which leads to a partial or total lyses of the cell.

Table 4. Comparison of the anticorrosion and microbial growth inhibiting properties of the substituted amino acids; inhibitor concentration: $500 \mathrm{ppm}$.

\begin{tabular}{|c|c|c|c|}
\hline NHM amino acid & $\begin{array}{l}\text { Anticorrosion } \\
\text { efficiency [\%] }\end{array}$ & $\begin{array}{l}\text { Inhibition of MIC in the } \\
\text { presence of Desulfovibrio } \\
\text { desulfuricans }\end{array}$ & $\begin{array}{l}\text { Inhibition of MIC in the } \\
\text { presence of mixed } \\
\text { population of cooling water }\end{array}$ \\
\hline NHM glycine & 88.2 & $\begin{array}{l}\text { effective on planktonic } \\
\text { population }\end{array}$ & only at high concentration \\
\hline NHM phenylalanine & 73.1 & $\begin{array}{l}\text { effective both on planktonic } \\
\text { microorganisms and on those } \\
\text { embedded in biofilm }\end{array}$ & effective \\
\hline NHM serine & 80.9 & $\begin{array}{l}\text { very effective inhibition of } \\
\text { planktonic microorganisms } \\
\text { and of those embedded in } \\
\text { biofilm }\end{array}$ & $\begin{array}{c}\text { very effective inhibition of } \\
\text { planktonic microorganisms } \\
\text { and of those embedded in } \\
\text { biofilm }\end{array}$ \\
\hline NHM glutamic acid & 68.2 & $\begin{array}{l}\text { very effective inhibition of } \\
\text { planktonic microorganisms } \\
\text { and of those embedded in } \\
\text { biofilm }\end{array}$ & $\begin{array}{c}\text { very effective inhibition of } \\
\text { planktonic microorganisms } \\
\text { and of those embedded in } \\
\text { biofilm }\end{array}$ \\
\hline
\end{tabular}

In order to learn more about the interaction of the NHM amino acids with the cell, quantum chemical indexes of the additives $\left(E_{\mathrm{HOMO}}\right.$ : energy level of the highest occupied electron orbital; $E_{\mathrm{LUMO}}$ : the lowest occupied electron orbital) were calculated with AM1 method [28]. The results are shown in the Table 5.

Table 5. The Quantum chemical characteristics of the NHM amino acids used as biocides.

\begin{tabular}{lccc}
\hline NHM amino acid & $\boldsymbol{E}_{\text {номо }}$ & $\boldsymbol{E}_{\text {LUмо }}$ & $\log [$ cell number in the biofilm] \\
\hline NHM glycine & -10.41 & 0.84 & 1.0 \\
NHM phenylalanine & -9.63 & 0.24 & 1.8 \\
NHM serine & -10.60 & 1.20 & 0.8 \\
NHM glutamic acid & -9.07 & 0.32 & 3.7 \\
\hline
\end{tabular}

These data showed that there is a connection between the highest occupied electron orbital and the logarithmic cell number:

$$
\log [\text { cell number }]=1.983 E_{\mathrm{HOMO}}+21.807
$$

The dependence of the $\log$ [cell number in the biofilm] on the $E_{\mathrm{HOMO}}$ refers to charge transfer between the cell surface and the NHM amino acid. 
In order to get deeper insight into the microbial system, another approach was also applied for our corrosion relevant microorganisms. We have started from the ChickWatson model [29-32]. Its main idea is that there is a correlation between the planktonic cell number and the number got with the multiplication of the biocide concentration and the time of its application:

$$
\log N / N_{0}=-k C_{(\text {mean })} t
$$

where $N$ is the cell number measured at the " $t$ " time, $N_{0}$ is the initial cell number, $C_{(\text {mean })}$ is the average biocide concentration, " $k$ " is the inactivation rate constant. We have applied this model but not for the planktonic cells but for the microbes embedded into the biofilm. Results are summarized in Table 6.

Table 6. Inactivation rate constants of NHM amino acids applied for both the anaerobic Desulfovibrio desulfuricans and for the mixed population of cooling water.

\begin{tabular}{|c|c|c|c|}
\hline $\begin{array}{l}\text { Desulfovibrio des. }+ \\
\text { NHM amino acid }\end{array}$ & 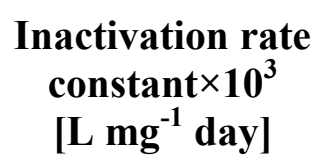 & 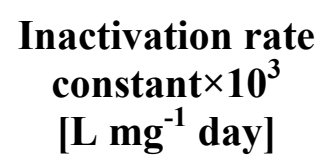 & $\begin{array}{c}\text { Inactivation rate } \\
\text { constant } \times 10^{3} \\
{\left[\mathrm{~L} \mathrm{mg}^{-1} \text { day }\right]}\end{array}$ \\
\hline & 2 days & 7 days & 14 days \\
\hline NHM glycine & 2.58 & 1.24 & 0.09 \\
\hline NHM phenylalanine & 5.60 & 1.25 & 0.39 \\
\hline NHM serine & 5.43 & 1.66 & 0.43 \\
\hline NHM glutamic acid & 4.28 & 1.91 & 0.55 \\
\hline \multirow[t]{2}{*}{$\begin{array}{l}\text { Cooling water }+ \\
\text { NHM amino acid }\end{array}$} & 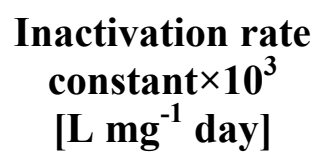 & 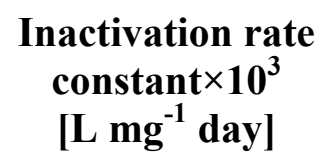 & 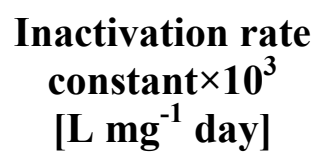 \\
\hline & 2 days & 7 days & 14 days \\
\hline NHM glycine & 4.75 & 1.32 & 0.41 \\
\hline NHM phenylalanine & 5.17 & 1.67 & 0.62 \\
\hline NHM serine & 5.16 & 1.52 & 0.85 \\
\hline NHM glutamic acid & 5.70 & 1.43 & 0.58 \\
\hline
\end{tabular}

Data in Table 6 proved that with increasing time the activity of the biocides decrease in the case when the biocide was added only at the beginning of the experiment. The degree of the diminution depends on the molecular structure. Those molecules (NHM serine and the NHM glutamic acid) which turned to be the most effective in the other microbial experiments, according to the results, summarized in Table 6, they are the best, with time increasing inhibitive activity against the corrosion relevant microorganisms. 


\section{Conclusion}

Our experiments with NHM amino acids proved that these molecules are active corrosion inhibitors and, at the same time, they can control the growth of corrosion relevant microorganisms. This statement is valid for both the planktonic microorganisms and for those ones embedded into biofilms. The cell numbers were drastically decreased even in the biolayer which is more difficult because of the penetration difficulty. The side chain in the amino acids play important role in the inhibition of either the corrosion or the microbial growth. As anticorrosion additive the phenylalanine could reduce effectively the corrosion rate (and, at the same time, it could effectively control the multiplication of the planktonic and embedded microorganisms). The NHM serine and NHM glutamic acids were very effective biocides. These results prove that with the same chemical both the electrochemical and microbial corrosion rates were significantly decreased, i.e. they are multifunctional additives in cooling systems. The undesired processes are regulated with one additive; it means that the load of the environment with chemicals could be significantly decreased.

\section{Acknowledgement}

The Authors express their thanks to Dr Imre Bakó for the quantum chemical calculations and for the visualization of the NHM amino acids.

\section{References}

1. B. Little, P. Wagner and F. Mansfeld, International Mat. Rev., 1991, 36, 253.

2. B. Little, P. Wagner, R. Raz, R. Pope and R. Scheetz, J. Ind. Microbiol., 1991, 8, 213.

3. M. Brennenstuhl, Corros. Sci., 1993, 35, 699.

4. P. Linhardt, Biodegradation, 1997, 8, 201.

5. J. Telegdi, Zs. Keresztes, G. Pálinkás, E. Kálmán and W. Sand, Appl. Phys. A, 1998, 66, 639.

6. Zs. Keresztes, T. Rigó, J. Telegdi and E. Kálmán, Appl. Phys. A, 2001, 72, 113.

7. G. Diósi, J. Telegdi, Gy. Farkas, L. G. Gazsó and E. Bokori, Int. Biodeterioration \& Biodegradation, 2003, 51, 151.

8. H. A. Videla, L. K. Herrera, Int. Microbiol., 2005, 8, 169.

9. P. Gümpel, N. Artl, J. Telegdi, D. Schiller and O. Moos, Mater. Corros., 2006, 57, 715. 10. J. Telegdi, E. Kálmán and F. H. Kármán, Corros. Sci., 1992, 33, 1099.

11. J. Telegdi, ACH Models in Chemistry, 1995, 132, 741.

12. Yu. I. Kuznetsov, Progress on the Understanding and Prevention of Corrosion, in The Phosphonate inhibitors of Metal Corrosion, Wiley-VCH, 1995, pp. 853-859.

13. E. Kálmán, I. Felhősi, F. H. Kármán, I. Lukovits, J. Telegdi and G. Pálinkás, Materials Science and Technology; A Comprehensive Treatment, Corrosion and Environmental Degradation, Eds. R. W. Chan, P. Haasen and E. J. Kramer, Wiley-VCH, 2000, Vol. 1, pp. $472-537$. 
14. J. Telegdi, M. M. Shaglouf， A. Shaban， F. H. Kármán， I. Bertóti， M. Mohai and E. Kálmán, Electrochim. Acta, 2001, 46, 3791.

15. D.-J. Choi, S.-J. You and J.-G. Kim, Materials Science and Engineering: A, 2002, 335, no. 1-2, 228.

16. I. Felhősi and E. Kálmán, Corros. Sci., 2005, 47, 695.

17. H. Amar, J. Benzakour, A. Derja, D. Villemin, B. Moreau and T. Braisaz, Appl. Surf. Sci., 2006, 252, 6162.

18. M. Prabakaran, M. Venkatesh, S. Ramesh and V. Periasamy, Appl. Surf. Sci., 2013, 276, 592.

19. S. Srinivasa Rao, B. V. Appa Rao, S. Roopas Kiran and B. Sreedhar, Journal of Materials Science \& Technology, 2014, 30, 77.

20. P. R. Unwin and R. G. Compton, J. Chem. Soc. Faraday Trans, 1990, 86, 1517.

21. R. J. Ross, K. C. Low and J. E. Shannon, Corrosion'96, NACE Press, 1996, Paper 162.

22. F. Liu, X. Lu, W. Yang, J. Lu, H. Zhong, X. Chang and C. Zhao, Desalination, 2013, 313, 18 .

23. F. Millet, R. Auvergne, S. Caillol, G. David, A. Manseri and N. Pébère, Progress in Organic Coatings, 2014, 77, 285.

24. W. G. Charaklis, Microbial Fouling Control, in: Biofouling (Eds. W. G. Charaklis and K. C. Marshall), J. Wiley, N.Y., 1990, pp. 585-633.

25. M. Podolak, S. Waga, and S. Przestalski, Pol. J. Environ. Stud., 1994, 3, 23.

26. D. H. Pope, T. P. Zintel, H. Aldrich and D. Duquette, Mater. Perform., 1990, 29, 49.

27. K. Russell and S. E. Jacob, Dermatitis, 2010, 21, 109.

28. J. Telegdi, E. Kálmán and F.H. Kármán, Hungarian Patent HU 214141 (1998).

29. J. J. Stewart, Comput. Chem., 1993, 10, 221.

30. H. Chick, Hygiene, 1908, 8, 92.

31. H. E. Watson, Hygiene, 1908, 8, 536.

32. B. Barbeau, Water Res., 1999, 33, 2941.

33. M. Sivaganesan, E. W. Rice and B. J. Mariňas, Water Res., 2003, 37, 4539. 